from seeking for the ultimate causes of hyperhemolysis and splenomegaly; the triumphs of the future in this newly opened field, like those of the past, can only come from patient correlation of work in the experimental laboratory, in the post-mortem room and in the clinic.

\section{(Original Artirlea.}

\section{ERGOTHERAPY IN THE TREATMENT OF MENTAL DISORDERS.}

\section{ly INa Charhotte Reid, M.D., San Franctsco.}

For centuries the unfortunate victims of mental disease were segregated and cared for simply because society had to be protected from them, and this was accomplished at the least possible expense and trouble to the community. They were considered as beings apart from ordinary humanity,-witches, monsters, "possessed of the devil." Those who were not burned at the stake or put to death in some such manner were locked up in cells, chained to posts or floors, placed in. stocks, straight-jackets, cribs or cages. The only attention they received was to be given sufficient nourishment to keep them alive. When Pinel, in 1745, struck from the inmates of the Salpêtriére the chains which had bound them for years, he instituted the era of the humase treatment of the mentally sick, and the civilized world began to realize that these unfortunate individuals were not necessarily dangerous to themselves or others. From that time the instruments of torture and restraint began to disappear from the asylums, and for another century the most advanced of these institutions considered they were doing their duty by their patients when they gave them humane, custodial care. It was not until the latter part of the last century that the subject of the treatment of mental disorders began to agitate the minds of the leading psychiatrists. It was very soon discovered that this long-neglected branch of therapeuties was worthy of investigation, and that much conld be accomplished toward the cure and amelioration of mental disease. As a result, in up-to-date hospitals for the insane, patients are being treated by psychanalysis, mental suggestion, sero-, radio-, hydro-, and ergotherapy.

Ergotherapy, or the work treatment, although to many it seems the most rational and productive of any of the general agents employed in the treatment of cases of mental disorder, is still neglected to a deplorable extent in our presentday institutions. Considering the importanec of work to the well-being of the normal mind as well as the body, its value in the treatment of the abnormal mind can readily be surmised. "Employment," said Galen, "is Nature's physician." In every place and under every circumstance, we see idleness conducive to unhappiness, mental, moral, and physical deterioration. The fact that employment can distract the mind from physical disorders, and stimulate the functions of the body, is being recognized and utilized by the medical profession in general. The phenomenal success of a sanatorium in California for the treatment of tuberculosis in wageearning women is no doubt partially due to the fact that they are engaged in an occupation which diverts their minds and defrays their expenses. Idly contemplating a long illness entailing great expense and enforced idleness for months, and perhaps years, would be sufficient, in the case of the average young person who is accustomed to work, to produce a mental depression which would almost prohibit recovery. Paranoia was once described as an "inability to forget." 'The average hospital for the insane gives its patients no chance to forget the past, and makes no attempt to substitute new interests for those left behind in the home, society or place of business. If forgetfulness of real or imaginary wrongs was difficult in the old environment, it is impossible in the new.

Although the patients in hospitals for the insane have for many years been encouraged, and in many cases forced to work, it was purely a question of economics, and not therapeutics. It is only within recent years that any attempt has been made in this country to utilize, in a systematic and scientific manner, occupation as a therapeutic measure. At the present time only sixty per cent. of the state hospitals in America are making such an attempt.

Last year, the American Médico-Psychological Association appointed a committee on diversional occupation of the insane, which reported, "Diversional occupation, scientifically and systematically applied, marks the standing of a hospital, and if neglected or omitted, the patients are not receiving the most modern care and treatment to which they are entitled."

Work may be made a great detriment or a valuable therapentic agent in the treatment of mental disorders, according to whether or not it is scientifically applied. In institutions where much of the hard labor is done by patients, and a certain ainount must be accomplished, the tendency is to make drudges out of the willing and efficient workers, and to allow to remain in complete idleness those who require to be instructed, supervised and handled with tact. Iset us consider the fate of a female patient suffering from dementia precox, and committted to the average state hospital, where little or no attention is paid by the plyssician in charge to the occupation of the patients. Shortly after the case is diagmosed, she is sent to a chronic ward. If she shows an inclination to work, she is given a trial in the laundry, sewing or dining rooms of the 
institution. If she proves careless or inefficient in her work, she is sent back to the ward. Because she allowed an "iron to burn out," spoiled a garment in the making, or broke a few dishes, many a poor soul has been condemned to perpetual idleness for the remainder of her life. Returned to a chronic ward, without any occupation or diversion, her life naturally falls into a dull and monotonous routine, unless she creates some diversion by assaulting those around her, tearing her clothes or destroying furniture. The notes on such a case show that each year she becomes a little more untidy, a little more indifferent, a little more demented, until she is completely "lospitalized," and as a result we see the finished product,-the untidy, indifferent, destructive, violent precox found in large numbers in every hospital for the insane, and constituting its greatest problem.

On the other hand, if a patient prove to be a willing and efficient worker, she is condemned to a life of hard labor. In every state institution we find old demented patients whose life has become an existence of hopeless dmudgery, with no time allowed them for recreation or diversion. 'This system of overworking patients has resulted in physical deterioration in many cases, and tuberculosis has been contracted. These patients being too demented to realize their failing strength, have gone on working in poorly ventilated workrooms until their condition became hopeless. Illustrative of this fact, was the case of an old woman recently under care in a state hospital. Seeing she was failing physically, she was given parole of the grounds, and urged to spend part of the day sitting in the open air. At first she replied, "No, no, I have not wasted a minute in ten years, and I can't lake the time to sit idly on the parole ground." Isfually pathetie, and illustrative of the harm done by overworking patients was a case who was transferred from another state institution. For months after her admission to that hospital, she worked in a poorly ventilated basement room, stitching overalls. She developed a cough, and folt that her strength was friling. Permission to discontinue her work was denied, as the institution was short of workers, so she decided to escape. 'The attempt was unsuccessful; she was brought back and placed in restraint, where she remained until transferred to my service. On admission, she was defiant and suspicious. When she found that she was not going to be compolled to work, she gradually changed her attitude, and at the present time has parole of the grounds, which she never abuses, spends part of her time doing fancy work, and is happy and contented.

The benefit; to be derived from the scientific application of ergotherapy will result in threefold advantage,- to the patient, the institution and the state. 'The busy patient is happier, more contented and deteriorates less rapidly than the idle one. If all the patients were employed, an institution would require fewer attendants, there would be less destruction of clothing and furniture, and the hospital, and consequently the state, would reap the benefit. In every hospital for the insane, public and private, there is a vast amount of energy going to waste that might be utilized to make the institution largely, if not completely, self-supporting.

In order to make ergotherapy effective in the treatment of mental disorders, there are three factors which are absolutely essential : first, physicians who are trained psychiatrists; second, vo. cational instructors; and third, nurses trained in the care of mental cases. Our concern is with the second essential.

Hery hospital for the treatment of mental cases should have one or more vocational instructors, whose duty it should be to consult with the physician in regard to the employment of individual cases, distribute the work to the various wards, instruct the murses in the oversight of the patients, conduct classes in the various occupations, attend to the purchase of materials and the sale of articles manufactured.

In order that patients who cannot receive instruction in classes should receive individual instruction, it is necessary to have nurses in charge of each ward trained in the care of mental cases and able to do some vocational work. I uarge hospitals for the insane all over the United States are establishing training schools for nurses, but very few of them include in their curriculum a course on the occupation and diversion of patients. In the Sheppard and Enoch Pratt Hospital, Maryland, such a course was established in 1912. This includes instruction in playing games, string work, paper folding, book-binding, basketry, embroidery, leather, wood and metal work. Each nurse, in addition to taking the course, is required to spend one month as assistant to the vocational instruetor. In small hospitals, however, it is impossible to organize training schools, and for that reason every state should have a training sehool for mental nursing, and only graduates from these or similar schools should be employed as charge nurses in state hospitals.

Having secured physicians who are experienced psychiatrists, vocational instructors and nurses trained in the care of mental, cases, it is possible to teach every patient, aside from senile and paretic eases, some useful oceupation which will make them partially or wholly self-supporting, and prevent habit deterioration. Pursuant to this idea, the writer has personally supervised the occupation of every new patient received on the female service of a state hospital for the past year. With the exception of two senile cases, and two cases of general paresis, every one of the sixty cases reccived has shown that she is capable of being taught to do some kind of work. Under the proper conditions, there is no reason why these patients should not continue to work so long as they are in the hospital. 
In order to accomplish the best results with ergotherapy, it is necessary to commence early. $\Lambda$ s soon as the patient becomes aceustomed to the new environment, and the initial exeitement has subsided, work should be insisted upon. Each individual case is a study in itself, and it is often necessary to change a patient many times before a suitable employment can be found. Individual tastes must be consulted. One of my patients refused to do anything but plain hand-sewing. She stated that the currents from the electric sewing machines affected her head, and all forms of fancy work she considered ummitigated foolishness. Another refused to do anything so prosaic as plain sewing, but loved to weave haskets, in which she intermingled in a wonderful manner colors of the most brilliant hue.

A new occupation is the most beneficial in convalescent cases and depressions, where there is a tendency to introspection and retrospection. The mental effort of. learning to clo something new distracts the mind and stimulates the faculties. On the other hand, dementing or demented cases often refuse to make the mental effort necessary to acquire even new motor reactions, and if disturbed in the rontine they have followed for years, they refuse to do anything.

It is likewise important that patients bo put to work on something obviously useful. No permanent improvement results from teaching patients to picee together picture puzzles, solve maze puzzles, place pegs in a board or fold paper. Even the most demented can see the futility of such proceedings, and soon tire of them. In the majority of cases, patients retain their interest in an occupation better when they receive some reward for their labor. This can be arranged by providing extras in food, clothing, more liberty, for those who work in sewing rooms, laundry and dining rooms, and by apportioning to each individual patient a certain percentage of the proceeds from the sale of work. 'This sum they can spend in any way their fancy dictates. Regarding the kind of work that can be done hy patients in a hospital for the insane, there is ano ordinary work that can not be done by them, if the work is adapted to the individual cases and they are properly instructed and supervised.

There are a few general rules which might be laid down in the application of the different kinds of work to different classes of cases. The only cases to which ergotherapy may be applied indiscriminately are the chronic alcoholic and drug habitues, which the already overerowded state hospitals of California have had thrust upon them. A careful olsservation of these cases, and testing by the Jinet scale, has shown that they belong largely to the moron type, and have an average mentality of a child about ten years of age. 'They are sufficiently high-grade to escape commitment to a home for the feebleminded, not sufficiently vicious to be sent to a prison or penitentiary, yet not sufficiently highgrade to avoid getting into trouble. These patients, coming as they do from the middle and lower classes of society, have been accustomed to hard work, and having no resources for entertaining themselves, weleome work as a relief from the monotony of institutional life.

'The work of the epilepties must necessarily be circumseribed and spasmodic. Nevertheless, they should be urged to employ themselves constantly at something. They should be encouraged, as a rule, to stick to one kind of work. After a time, its performance becomes mechanical, and as dementia proceeds, the motor reaction takes place without the expenditure of any mental effort. I have frequently seen epileptic women so demented that they could scarcely tell their own names, who conld crochet or embroider with unusual skill.

'The treatment of the manic-depressive psychosis by ergotherapy is a problem which demands long experience, careful study and ohservation of individual cases. If the hypomania which so often precedes an attack of mania were diagnosed and treated by the general practitioner by the removal of the mental stress and strain incident to school or eollege work, business, professional or society life, and a complete ehange and rest ordered, many a case of manic-depres. sive insanity would be spared the inconvenience. and humiliation of being committed to a hospital for the insane. By the time such cases are received at the hospital, the excitement is usually well developed, and the apparent superabundant energy of the patient is being wasted prodigally in purposeless, if not harmful, activity. 'T'o attempt to limit this aetivity by physical restraint is worse than useless, but to direct it into useful chamnels is a task which calls for the greatest skill, patience and tact. The more like play the work ean be made the better, and it should be such as to eall for no continued mental effort or exercise of patience on the part of the patient. It is often necessary to try first one kind of employment and then another. If the patient can be made to work only a few minutes on the first trial, the length of time can be gradually increased. These patients often have a dominating idea of reforming everyone and everything about them. and it is sometimes well to take advantage of this idea. I recall one manic-depressive who regularly, during her excitements, undertook the reformation and re-edneation of a case of dementia preeox on the same ward. She taught her to dress herself, comb her hair and help with the ward work. The excitement of others may take the form of a graphomania, and these patients can be encouraged to write letters for patients who cannot do it for themselves. I re. call another manic-depressive case who took it upon herself to renew the interest of several neglectful relatives of patients on her ward. 'This 
she did by writing lengthy epistles, appealing to them in various ways, and some of these letters accomplished their purpose.

During an oncoming depression of manicdepressive insanity, I believe work is, as a rule, harmful, and these patients should be relieved from the discharge of all duties, and if possible, be made to remain in bed. A manic-depressive formerly under my care told me that for years before her admission to a hospital she had warded off depressions by dropping all her household cares and social obligations when the first symptoms appeared, and going away for a rest. She likewise stated that even to dress herself seemed such a gigantic undertaking that she would lie awake and wonder how she could accomplish it. A patient who formerly had a depression every few months has been under my eare for the past year, and has not had an attack during that time. $\Lambda$ s soon as I noticed the slightest change in her appearance or demeanor I made her discontinue all work, and ordered rest in bed and hydrotherapy. She herself is confident that at least two depressions have been warded off in this manner. When convalescence is established, interesting and absorbing occupation should be furnished.

Jementia precox, like manic-depressive insanity, often shows itself during a period of unusual mental or physical strain, with the difference, however, that as the excitement of a manic depressive increases he becomes more and more \%ealous in his work, oversteps the limit of his authority and over estimates his strength and ability, while the precox gradually loses interest in his work, becomes indifferent, apathetic and often hypochondriacal. These patients, on admission to a hospital, usually give a long history of having drifted from one occupation to another, their failing efficiency being evidenced by a gradual decrease in salary.

In view of the fact that more than one-half of the permanent population of hospitals for the insane is composed of cases of dementia precox, it would seem that this class of cases offer's the best field for operations in ergotherapy. 'The importance of preventing habit deterioration by early and systematic cultivation of the work habit is evident. Perhaps the first hospital in the United States to make any attempt to progress along this line was the 'Taunton State IIospital, Massachusetts. Dr. George C. S. Choate, the superintendent, in his Ammual Report of 1854, gave it as his opinion that two-thirds of the patients in his lospital were capable of (amployment of some sort. Although the work there has been allowed to lapse somewhat from time to time, the report of that hospital for 1912 shows that seventy-four per cent. of the patients are working. In the New York state hospitals considerable work is being done in the reedlucation of advanced cases of dementia precox, with good results. At the Government IIospital for the Insane, Washington, 1). C., a series of ex- periments were undertaken by Dr. Helen Grace Kent and Mr. F. G. lioring, to ascertain the extent to which this re-education could be carried. The principle conclusions drawn by Dr. Kent from several months' work were: “'(1) Definite practice effects can be obtained by means of a short series of tests from advanced cases of dementia precox. (2) Practice effects are transferable from one kind of work to another, differing in perpetual but not in motor aspect. (3) Energy expended in mischievous performances may be directed into favorable channels." Mr. Boring's experiments, which included the teaching of rug making, showed similar results, with the additional conclusion that, "Patients suffering from dementia precox are capable in simple industrial operations of a quality of work sufficiently good to be of commercial value." These experiments, which consisted of arrang. ing and cancelling digits, identifying geometrical figures, solving maze puzzles, etc., had the disadvantage, with the exception of the rugmaking, of lacking appeal to the patient's esthetic or industrial sense. They could see nothing to be gained by such exercises, and consequently lost interest.

'T'o re-educate the vast army of demented patients in our hospitals for the insane, would be a task which would involve an expenditure of time, energy and money which, in all probability, would not he warranted by the results obtained. The new cases of dementia precox can, however, with comparatively little trouble, be directed into better paths, to the end that the chronic wards in hospitals for the insane will be fillod with patients who, although demented, will be quiet, tidy, industrious and contented.

TUE USE OF A SEC'TION OF THE SCAP. ULA IN CORRECTING A NASAL DEFORMITY.

BY OLIFer A. Lothrop, M.D., Boston,

Issistant Otoloyist, Massarhusetts General Hospital; Clinical Assistant, Massachusetts Charitable Eye and Ear Infirmary; Assistant in Otology, llarvard Medical School.

'Tus various types of nasal deformity require entirely different operative procedures for their correction. The simplest type is that of the fracture-dislocation of the nasal bones, and the operation required in such cases consists in a re-fracture and then a reduction of the dislocation. $\Lambda$ second type is exemplified in the lateral deviation of the cartilaginous portion of the nose. Another type may be noted in the arpuiline deformity which recuires a speeial technie for reduction." 'The irregular humps often * An Operation for Correcting the Aquiline Nasal Deformity, Boston Medicat and Slbifcal. Jounial, May 28, 1014, Vol. clxx. p. 835 . 